\title{
Development of an evidence-based strategy to assess and manage substance use in oncology patients
}

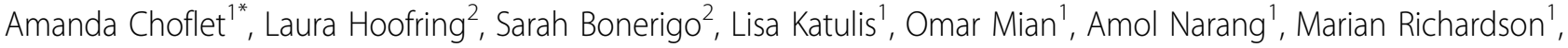 \\ Sue Appling ${ }^{3}$
}

From INEBRIA 12th Congress,

Atlanda, GA, USA. 24-25 September 2015

\section{Background}

This project will empower cancer patients to address their substance use by establishing an evidence-based strategy for identifying and managing substance use during cancer treatment.

The question is: Does the proactive identification and management of substance use in oncology patients improve specific patient outcomes such as quality of life, treatment adherence, and reduction in treatment complications?

A multidisciplinary team identified substance use as a contributing factor in several adverse patient outcomes. Further research revealed that there are currently no evidence-based standards to guide the care of patients with alcohol and illicit substance use (AISU) who are diagnosed with cancer. AISU during cancer treatment significantly worsens quality of life outcomes, including problems with pain, sleep, dyspnea, total distress, anxiety, coping, shortness of breath, diarrhea, poor emotional functioning, fatigue and poor appetite[1-4]. AISU in cancer patients may also cause significant safety risks in the short and long term[5-9] and increased mortality [10]. After completing a literature review and an exhaustive needs assessment, the team developed a program to implement Screening, Brief Intervention, and Referral to Therapy (SBIRT) in the outpatient radiation oncology department. The implementation plan includes motivational interviewing training, clinical pathways, and risk-based intervention toolkits that will incorporate oncology-specific resources.

* Correspondence: achofle1@jhmi.edu

${ }^{1}$ Radiation Oncology, Johns Hopkins Hospital, Baltimore, USA

Full list of author information is available at the end of the article

\section{Conclusions}

AISU in cancer patients is a threat to safety and quality of life, and patients who use substances during cancer treatment represent an opportunity to improve wellness in a vulnerable population. A program that incorporates the use of SBIRT as part of routine patient care should improve both cancer-specific and all-cause patient outcomes and is critical to patient safety.

\section{Material and methods}

Three evidence-based methods will be implemented to address substance use in cancer patients. Inter-professional instructional design will be provided to nurses and resident physicians to prepare front-line staff to implement a screening, brief intervention, and referral to therapy (SBIRT) program. This instruction will consist of SBIRT-focused motivational interviewing training utilizing standardized patients and coaching support. Following this training, staff will implement risk-based clinical pathways based on validated assessment instruments. Finally, oncology-specific toolkits will be implemented, which will include referral instructions and resources, oncology-specific risk sheets, and validated SBIRT educational items.

\section{Results}

Nurses and residents will complete surveys regarding their knowledge, skills, and attitudes. Screening, brief intervention, and referral rates will also be gathered retrospectively.

\section{Acknowledgements \\ Dr. Theodore DeWeese, MD \\ Dr. Sharon Krumm, PhD, RN}




\section{Authors' details}

'Radiation Oncology, Johns Hopkins Hospital, Baltimore, USA. ²Department of Oncology, Johns Hopkins Hospital, Baltimore, USA. ${ }^{3}$ Johns Hopkins University School of Nursing, Baltimore, USA.

Published: 24 September 2015

\section{References}

1. Danker H, Keszte J, Singer S, Thomä J, Täschner R, Brähler E, Dietz A: Alcohol consumption after laryngectomy. Clinical Otolaryngology: Official Journal of ENT-UK?; Official Journal of Netherlands Society for Oto-RhinoLaryngology \& Cervico-Facial Surgery 2011, 36(4):336-344, doi:10.1111/j.17494486.2011.02355.x.

2. Koyyalagunta D: Risk Stratification of Opioid Misuse among Patients with Cancer Pain Using the SOAPP-SF. Pain Medicine (United States) 2013, 14(5):667-675, doi:10.1111/pme.12100

3. Modesto-Lowe V, Girard L, Chaplin M: Cancer pain in the opioid-addicted patient: can we treat it right? Journal of Opioid Management 2012, 8(3):167-175, doi:10.5055/jom.2012.0113.

4. Parsons H A, Delgado-Guay M O, El Osta B, Chacko R, Poulter V, Palmer J L, Bruera E: Alcoholism screening in patients with advanced cancer: impact on symptom burden and opioid use. Journal of Palliative Medicine 2008, 11(7):964-968, doi:10.1089/jpm.2008.0037.

5. Chang C-C, Kao H-K, Huang J-J, Tsao C-K, Cheng M-H, Wei F-C: Postoperative alcohol withdrawal syndrome and neuropsychological disorder in patients after head and neck cancer ablation followed by microsurgical free tissue transfer. Journal of Reconstructive Microsurgery 2013, 29(2):131-136, doi:10.1055/s-0032-1329927.

6. Genther D J, Gourin C G: The effect of alcohol abuse and alcohol withdrawal on short-term outcomes and cost of care after head and neck cancer surgery. The Laryngoscope 2012, 122(8):1739-1747, doi:10.1002/lary.23348.

7. Neuenschwander A U, Pedersen J H, Krasnik M, Tønnesen H: Impaired postoperative outcome in chronic alcohol abusers after curative resection for lung cancer. European Journal of Cardio-Thoracic Surgery: Official Journal of the European Association for Cardio-Thoracic Surgery 2002, 22(2):287-291, doi: 10.1016/S1010-7940(02)00263-4.

8. Wu I-C, Wu C-C, Lu C-Y, Hsu W-H, Wu M-C, Lee J-Y, Wu M-T: Substance use (alcohol, areca nut and cigarette) is associated with poor prognosis of esophageal squamous cell carcinoma. PloS One 2013, 8(2)-e55834, doi:10.1371/journal.pone.0055834.

9. Breslow R A, Chen C M, Graubard B I, Mukamal K J: Prospective study of alcohol consumption quantity and frequency and cancer-specific mortality in the US population. American Journal of Epidemiology 2011, 174(9):1044-1053, doi:10.1093/aje/kwr210.

\section{Submit your next manuscript to BioMed Central and take full advantage of:}

- Convenient online submission

- Thorough peer review

- No space constraints or color figure charges

- Immediate publication on acceptance

- Inclusion in PubMed, CAS, Scopus and Google Scholar

- Research which is freely available for redistribution

Submit your manuscript at www.biomedcentral.com/submit 